\title{
Sources of the Maelstrom
}

Theser he Lofoten Maelstrom on the northern coast of Norway has been renowned for centuries for its strength and dangerous whirlpools. We now complete a previous review $^{1}$ of the historic literature about the Maelstrom and present results of simulations describing the large-scale dynamics of this remarkable phenomenon.

The Maelstrom is located at $67^{\circ} 48^{\prime} \mathrm{N}$, $12^{\circ} 50^{\prime}$ E between Lofoten Point (Lofotodden) and the island Værøy southwest of the main chain of the Lofoten Islands, and takes its name, Moskstraumen, from the small island Mosken in the centre (Figs 1, 2). The current is of tidal origin, although the prevailing northward currents and southwesterly wind may contribute to its strength. It is said to run at a speed of up to 5 or $6 \mathrm{~m} \mathrm{~s}^{-1}$, but no current records are available for estimates of these extremes. Eddies and current shear-zones appear on satellite images ${ }^{2}$.

The earliest accounts of the Maelstrom survive in old Nordic tales ${ }^{3}$. They tell of a pair of ponderous and magical millstones which sank either near the Pentland Firth north of Scotland or on the northwestern coast of Norway. Their continuous grinding of salt is said to form large eddies in the sea above. The term maelstrom is commonly thought to derive from the Dutch verb malen (Nordic male) meaning 'to grind'.
The first written account is probably by Olaus Magnus (1490-1558), a Swedish bishop in Rome ${ }^{4}$. On Charta Marina (1539) he drew a large eddy west of Lofoten, which he described as stronger than the Sicilian Charybdis, and attributed it to a divine force. Subsequently, fictional descriptions of a huge eddy appeared, were reprinted, and cited in mainstream seventeenth and eighteenth century European geographical literature ${ }^{1}$. Contemporary Norwegian authors gave more factual descriptions ${ }^{5-8}$.

Petter Dass (1647-1707), a Norwegian priest, produced a detailed and realistic description of Moskstraumen, as well as other strong tidal currents, in his poem, The Trumpet of Nordland ${ }^{6}$, written around 1685. He attributed its strength to the phases of the Moon - the current being strongest at full and new moons and weakest at half moons. Unfortunately, Dass was not translated into English. A report by Schelderup ${ }^{7}$ (written before 1751), noted the rotation of the current during the tidal cycle and attributed the driving force to differences in sea level across the Lofoten islands.

The celebrated stories by Edgar Allan Poe (A Descent into the Maelström, 1841) and Jules Verne (Vingt Mille Lieues sous la Mer, 1869), featuring the Lofoten Charybdis, rely heavily on Nordic sources. Poe's detailed

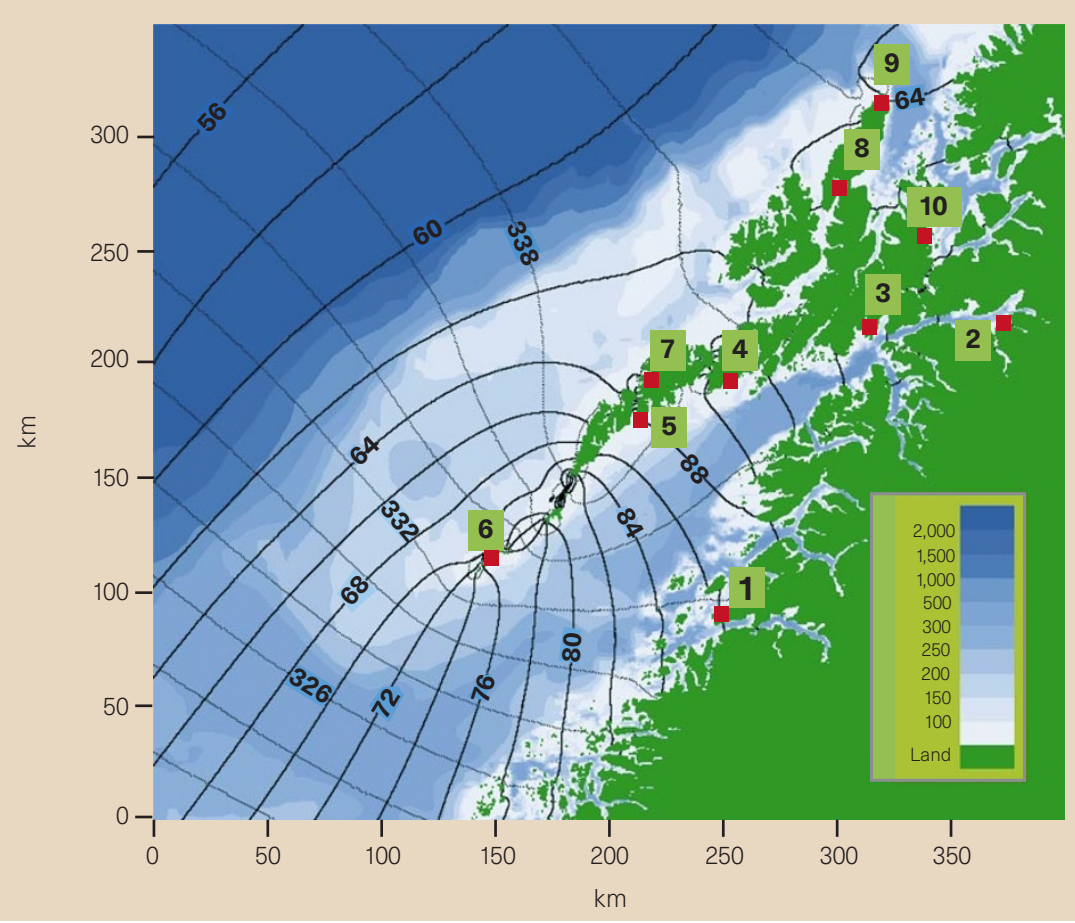

Figure 1 Modelled sea-level amplitude and phase for the dominant semi-diurnal tidal component $\left(\mathrm{M}_{2}\right)$. The Lofoten Islands extend northeast from Røst (6), to Lødingen (3). Vestforden between Lofoten and Bodø (1), Narvik (2), Andenes (9) and Harstad (10). Colour depth-scale is in metres. Solid contour lines show amplitude (in cm) with 2-cm separation. Dotted contour lines indicate phase (deg, GMT) with 2 deg separation. A decrease of 2 deg in phase corresponds to a time delay of the tide of $4 \mathrm{~min}$. Observed/modelled amplitude (in $\mathrm{cm}$ ) for the stations 1-10: 87/86, 99/100, 93/96, 93/92, 88/89, 78/76, 62/63, 68/66, 65/63 and 69/66, respectively. knowledge of the landscape and local tales, can be traced back to a fictitious description by Jonas Ramus from about 1715, which includes elements from an older source 5 . Ramus's description was quoted by Pontoppidan $^{8}$ and reprinted in the sixth edition of Encyclopaedia Britannica (1823). Poe also acquired some information on local fishing practice, probably through the Anglo-American sources mentioned by Mabbott ${ }^{9}$.

No substantial modern studies of this strong tidal current have been reported. The Norwegian pilot book ${ }^{10}$ provides some information albeit of limited scientific value. We have therefore developed a highresolution depth-integrated tidal model with a $0.5 \mathrm{~km}$ grid size (Fig. 1). This has enabled a study of the transition of the tide from a northwards progressive wave ${ }^{11}$ on the outer shelf to standing oscillations in the fjords, and the enhancement of the tidal current particularly around Lofotodden. Input on lateral boundaries (sea level and volume flux) were obtained by interpolation from coarser models ${ }^{11,12}$.

The simulated amplitude and phase for the dominant semi-diurnal tidal component $\mathrm{M}_{2}$ (Fig. 1) agree well with observations. A strong sea-level gradient appears across the island chain with up to $25 \mathrm{~cm}$ higher amplitudes in Vestfjorden inside the islands than outside. This drives the current around Lofotodden and through the narrow channels between the islands further east. The sea-level variation, with contour lines converging on Lofotodden (Fig. 1) is due to the change in shelf width from a relatively broad shelf south of Lofoten to a narrow shelf further north, and the scatter-

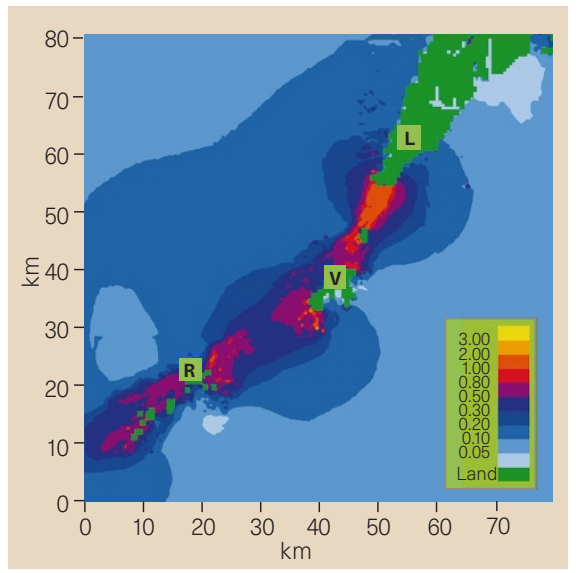

Figure 2 Maximum depth mean current for $M_{2}$ in the area southwest of Lofotodden ( $L$ ) with Værøy $(V)$ and Røst (R). Mosken is midway between $L$ and $V$. Colour scale is in $\mathrm{m} \mathrm{s}^{-1}$. Volume flux through the sections between $L$ and $V$ and between $V$ and $R$ are $0.35 \times 10^{6} \mathrm{~m}^{3} \mathrm{~s}^{-1}$ and $0.55 \times 10^{6} \mathrm{~m}^{3} \mathrm{~s}^{-1}$, respectively, at the peak of the tide. Volume fluxes at spring tide are 1.8 times larger. 
ing of the northbound tidal wave by the islands and shallow bank to the southwest.

The mean currents are predicted to be of the order of $0.1 \mathrm{~m} \mathrm{~s}^{-1}$ in deep water and up to $3.0 \mathrm{~m} \mathrm{~s}^{-1}$ on the narrow ridge $(50-100 \mathrm{~m}$ deep) between Lofotodden and Røst (Fig. 2). A lack of data from this area hampers validation of the model; however, we have made comparisons with measurements from channels between the islands east of Lofotodden at Napp, Sundklakk and Gimsøy. Current shifts are predicted to occur about $2 \mathrm{~h}$ before high water, with a northwards current at high water and a southwards current at low water, in agreement with observations ${ }^{10}$.

A weak, roughly 6-km diameter, clockwise eddy appears in the simulations, centred about $5 \mathrm{~km}$ southwest of Lofotodden at the time of current shift on a rising sea. A similar sized anticlockwise eddy appears nearer Lofotodden at the time of current shift on falling sea. The current speed in these eddies is roughly $0.1 \mathrm{~m} \mathrm{~s}^{-1}$, no comparison to the eddy in ancient literature. The eddies owe their existence to sea-floor topography and friction. West and east of Mosken the current vector rotates clockwise in nearly circular ellipses which may have been interpreted as a large eddy by early observers.

The semi-diurnal components, $\mathrm{S}_{2}$ and $\mathrm{N}_{2}$, show a similar amplitude pattern to $\mathrm{M}_{2}$. The diurnal component, $K_{1}$, which interacts with shelf wave modes, produces dominant diurnal currents in Sortlandsundet between stations 7 and 8 (Fig. 1), where the $\mathrm{M}_{2}$ current is weak, matching observations (Norwegian Hydrographic Service, 1994). The generation and advection of small-scale eddies in the strong tidal jet remain a subject for future studies but these local effects are not likely to alter the large-scale patterns of sea-level variations reported here.

\section{B. Gjevik, H. Moe}

\section{A. Ommundsen}

Department of Mathematics, University of Oslo, 0316 Blindern, Oslo, Norway

e-mail:bjorng@math.uio.no

1. Peterson, R. G., Stramma, L. \& Kortum, G. Progr. Oceanogr. 37, 1-115 (1996).

2. Wahl, T. Nordic Space Activities 2-3, 22-23 (1995).

3. Guerber, H. A. The Norsemen 128-130 (Senate Studio Editions, London, 1994).

4. Magnus, O. Historia om de Nordiska Folken Swedish edn, 89-90 (Gidlunds, Stockholm, 1982; first published Rome, 1555).

5. Schønnebøl, E. H. in Historisk-Topografiske Skrifter om Norge og Norske Landsdele (ed. Storm, G.) 178-218 (A. W. Brøggers Bogtrykkeri, Christiania, Oslo, 1895; original from c. 1590).

6. Dass, P. Nordlands Trompet (ed. Seip, D. A.) 94-98 (Aschehoug, Oslo, 1947).

7. Schelderup, A. Kongelige Norske Videnskabersselskabs Skrifter 2, 1, 78-85 (Trondheim, Norway, 1824).

8. Pontoppidan, E. Norges Naturlige Historie 123-140 (Reprint by Rosenkilde og Bagger, Copenhagen, 1977; first printed Copenhagen, 1752; English edn, London, 1755).

9. Mabbott T. O. Collected works of Edgar Allan Poe II, 574-597 (Belknap, Cambridge, MA, 1978).

10. Den Norske Los 5, 6th edn, 241-242 (Norwegian Hydrographic Serv., Stavanger, 1987)

11. Gjevik, B. in Modeling Marine Systems (ed. Davies, A. M.) I 187-219 (CRC Press Inc, Boca Raton, Florida, 1990).

12. Gjevik, B., Nøst E. \& Straume T. J. Geophys. Res. 99, C2, 3337-3350 (1994).

\section{Morbillivirus in monk seal mass mortality}

We have identified a morbillivirus in organs of Mediterranean monk seals (Monachus monachus), lost during a recent mass dieoff. About half of the population of this highly endangered species, which inhabits the Mauritanian coast of West Africa (Cap Blanc), were killed. The outbreak is reminiscent of several recent morbillivirus outbreaks in aquatic mammals.

In 1988 there was a mass die-off of the two indigenous seal species of northwestern Europe, eventually leading to the deaths of about 20,000 animals. We and others identified a previously unrecognized morbillivirus, phocine distemper virus (PDV), as its primary cause. In subsequent years, several other mass mortalities of pinniped and cetacean species could be attributed to infections with known and newly identified morbilliviruses ${ }^{1,2}$. This prompted us to speculate about the possible threat of morbillivirus infections to highly endangered pinnipeds like the Mediterranean monk seal (Monachus monachus) $^{3}$. Two subpopulations of this species exist, one living off the Mediterranean coasts and the other off the Mauritanian coast of West Africa (Cap Blanc), with estimated population sizes of about 500 and 270 animals, respectively.

We and others have observed significant mortality in the West African population since May this year. After finding about 40 dead animals in and around the two caves that they predominantly inhabit, it became clear that a serious disease outbreak was ongoing, which eventually killed more than half of the total population. We autopsied several animals that had washed ashore during the outbreak. Most of these were in a state of advanced decomposition, probably because of the long period before washing ashore and the high ambient temperature. It was clear however, that most of these animals had suffered from respiratory distress, as emphysema and congestion of the lungs were among the most frequent macroscopic findings, consistent with previous morbillivirus infections of seals ${ }^{2}$.

In an enzyme-linked immunosorbent assay $^{3}$ for the detection of serum antibodies to canine distemper virus $(\mathrm{CDV})^{1}$, seven of 17 samples collected from the hearts of dead animals scored positive. We carried out virological analysis using organ samples from the 14 least decomposed carcasses. Using standard procedures ${ }^{2}$ we isolated a cytopathic virus in Vero cells from lung and other organ samples of three of these animals. This virus also proved to be infectious for ferrets on parenteral infection. Our preliminary characterization of the virus with polyclonal and monoclonal antibodies ${ }^{3}$ showed that the virus is a morbillivirus, probably different from CDV and PDV (data not shown).

We isolated total nucleic acids from lung samples with the guanidinium method ${ }^{4}$ and analysed them with a reverse transcriptase polymerase chain reaction (RT-PCR) using random hexanucleotides for first-strand synthesis. We used group-specific primers for the genus Morbillivirus, which recognize the $N$ gene (primer 1: 5'-ACAAACCANGGATTGCTGAAATGAT-3' and primer 2: $\quad$ 5'-CTGAAYTTGTTCTGAAYTGAGTTCT- $\left.3^{\prime}\right)$ for amplification ${ }^{5}$. A semi-nested PCR using primer 2 and primer 3 (5' -ATCGARACWATGTACCCGGC-3') increased the PCR signal for direct sequencing.

Sequencing allowed us to make a phylogenetic comparison with other morbilliviruses, using the Phylogeny Interference Package (provided by J. Felsenstein). We generated a maximum-likelihood tree, and assessed its stability using a bootstrap method (Fig. 1). We found the virus to be most closely related (mean distance, 0.030 ) to the previously described dolphin morbillivirus $(\mathrm{DMV})^{2}$. The antigenic difference between CDV and the isolated virus, the suboptimal state of the samples, and the fact that morbillivirus infections cause profound immunosuppression, may collectively explain why not all the dead monk seals tested had developed antibodies to CDV.

Further studies, preferably of live and freshly autopsied animals, are needed to confirm that this outbreak, reminiscent of many recent morbillivirus outbreaks in aquatic mammals, is indeed caused by infection with this newly identified monk seal morbillivirus (MSMV). In this light it is noteworthy that we could not detect the

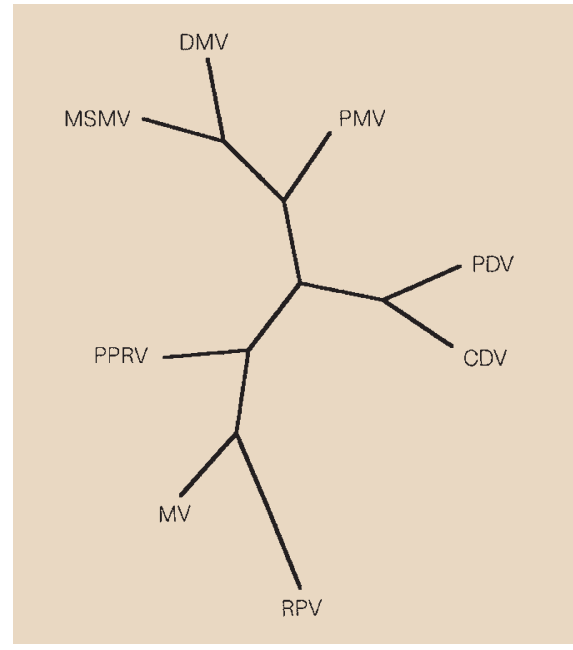

Figure $1 \mathrm{~A}$ maximum likelihood tree of $\mathrm{N}$ protein fragment sequences (121 nucleotides) of different morbilliviruses. DMV, dolphin morbillivirus; PMV, porpoise morbillivirus; PDV, phocine distemper virus; $\mathrm{CDV}$, canine distemper virus; RPV, rinderpest virus; $M V$, measles virus; PPRV, peste des petits ruminants virus; MSMV, monk seal morbillivirus. 